\title{
Crustal and uppermost mantle structure of Caucasus and surrounding regions*
}

\author{
Youshun Sun ${ }^{1,2, \star} \quad$ M Nafi Toksöz ${ }^{2} \quad$ Randolph J Martin ${ }^{3}$ \\ Mary Krasovec ${ }^{3}$ Diming $\mathrm{Yu}^{2} \quad$ Qingyun $\mathrm{Liu}^{2}$ and $\mathrm{Jun} \mathrm{Liu}^{2,4}$ \\ ${ }^{1}$ State Key Laboratory of Geodesy and Earth's Dynamics, Institute of Geodesy and Geophysics, \\ Chinese Academy of Sciences, Wuhan 430077, China \\ ${ }^{2}$ Department of Earth, Atmospheric and Planetary Sciences, Massachusetts Institute of Technology, \\ Cambridge, MA 02139, USA \\ ${ }^{3}$ New England Research, Inc., White River Jct., VT 05001, USA \\ ${ }^{4}$ School of Civil Engineering and Architecture, Wuhan University of Technology, Wuhan 430070, China
}

\begin{abstract}
A 3-D P-wave velocity model is developed for the crust and uppermost mantle of Caucasus and the surrounding area by applying the tomographic method of Zhao et al. using 300000 high-quality P-wave first arrivals from 43000 events between 1964 and 2005. This tomographic method can accommodate velocity discontinuities such as the Moho in addition to smooth velocity variations. The spatial resolution is $1^{\circ} \times 1^{\circ}$ in the horizontal direction and $10 \mathrm{~km}$ in depth. The velocity images of the upper crust correspond well with the surface geology. Beneath the southern Caucasus high velocity anomalies are found in the middle crust and low velocity anomalies are found in the uppermost mantle. Relatively low Pn velocities are located under the Lesser Caucasus, eastern Turkey, and northern Iran. Higher Pn velocities occur under the eastern portion of the Black Sea and the southern Caspian Sea, and also extend into the eastern edge of Azerbaijan. Tomographic model significantly reduces the travel-time residuals.
\end{abstract}

Key words: Caucasus region; crustal structure; Pn velocity; 3-D tomography

CLC number: P315.2 Document code: A

\section{Introduction}

The structure of the Caucasus mountain region and surrounding areas is primarily controlled by the collision and continuing convergence of the Arabian and Eurasian plates. The Arabian and Eurasian plates collided in the Early Miocene after the Neo-Tethys Sea was subducted beneath Eurasia, and several tectonic features were formed as a result of the collision. The Caucasus mountains, an orogenic belt that was uplifted as a consequence of the collision, have elevations over $5 \mathrm{~km}$ above sea level and extend $1300 \mathrm{~km}$ in a NW-SE direction between the Black Sea and southern Caspian Sea

\footnotetext{
* Received 11 September 2012; accepted in revised form 20 October 2012; published 10 December 2012.

* Corresponding author. e-mail: youshun007@yahoo.com

(c) The Seismological Society of China, Institute of Geophysics, China Earthquake Administration, and Springer-Verlag Berlin Heidelberg 2012
}

basins. The Rioni basin in the west and the Kura basin in the east dissect this orogenic belt into two parts separating the Greater Caucasus in the north from the Lesser Caucasus in the south. These two basins are separated by the transCaucasian Dzirula massif in the middle. The Greater Caucasus ranges consist mostly of Paleozoic metasedimentary rocks and granitoids, Jurassic sediments, Mesozoic and Cenozoic volcanics (Adamia et al., 1977; Khain, 1984). The Lesser Caucasus ranges consist of Paleozoic granitoid-metamorphic basement overlain unconformably by shelf carbonates of Paleozoic-Triassic age. They also contain ophiolite mélange lithologies of the Sevan-Akera and the Vedi suture zones. The basement rocks and the ophiolites are overlain by the extensive volcano-sedimentary sequence of Late Eocene-Early Miocene age (Khain, 1984; Koçyiğit et al., 2001).

The collision of the Arabian and Eurasian plates also played a part role in the formation of the Black 
Sea and southern Caspian Sea basins. The Black Sea is generally thought to have a basement of oceanic crust that is overlain with $10-20 \mathrm{~km}$ of sediment. Similarly, the basement of the southern Caspian Sea basin has geophysical attributes like that of thick oceanic crust and is overlain by $\sim 20 \mathrm{~km}$ of sedimentary cover (Mangino and Priestley, 1998). The continuing convergence in the region continues to affect the deformation, tectonic structure, and seismicity of the region.

In general folding, thrusting and high angle reverse faulting are the most dominant forms of deformation in the Caucasus region. The fault mechanism solutions for the earthquakes indicate predominantly thrust events with NW-SE trending fault planes (McKenzie, 1972; Jackson and McKenzie, 1984; Jackson, 1992; Cisternas and Philip, 1997; Jackson et al., 2002). Recent GPS measurements provide valuable information regarding the active deformation of the Caucasus region (Reilinger et al., 1997, 2006; McClusky et al., 2000). Estimates of the overall N-S shortening across both the Greater and Lesser Caucasus are approximately $10 \pm 2 \mathrm{~mm} / \mathrm{a}$ of which $\sim 60 \%$ is accommodated by the Greater Caucasus (Reilinger et al., 1997; McClusky et al., 2000). These studies indicate, however, that there is little internal shortening within the Greater Caucasus and that the present rate of shortening across the Caucasus cannot account for all the observed strain in the region.

The seismicity of the region is predominantly controlled by the continuing convergence of the Arabian and Eurasian plates. A number of large (M6.5-7.0) earthquakes have occurred in the Caucasus within the last decade. For example, the Spitak earthquake of December 7, $1988\left(M_{\mathrm{S}} 6.9\right)$ occurred in the Lesser Caucasus region, along the Pambak-Sevan thrust fault at a depth of $10 \mathrm{~km}$, and the Racha earthquake of April 29, $1991\left(M_{\mathrm{S}} 7.0\right)$ occurred in the Greater Caucasus region along a thrust zone between the Greater Caucasus and the Dzirula massif at a depth between $3 \mathrm{~km}$ and $10 \mathrm{~km}$ (Triep et al., 1995). Overall, large magnitude earthquakes are mainly located near the margins of the range, and seismicity is higher to the east of the Caucasus mountains (Jackson, 1992) and most earthquakes are located between $10-40 \mathrm{~km}$ depth in the crust. The interior of the southern Caspian Sea is relatively aseismic, though intermediate depth earthquakes with depths of $\sim 80 \mathrm{~km}$ are located in north of the southern Caspian basin, suggesting northward underthrusting beneath the middle Caspian region (Jackson et al., 2002).

A number of studies have examined the crust and uppermost mantle structure across the ArabianEurasian collision zone. Large scale Pn wave tomographic studies show large variations in crustal thickness and uppermost mantle velocities within the Caucasus region. Slow $\mathrm{Pn}$ velocities $(8 \mathrm{~km} / \mathrm{s})$ were found beneath the Anatolian plateau and the Greater Caucasus, and very low Pn velocities $(7.8 \mathrm{~km} / \mathrm{s})$ were located beneath the Lesser Caucasus (Ritzwoller et al., 1998; Hearn and Ni, 1994; Al-Lazki et al., 2004). Relatively fast Pn velocities $(>8.0 \mathrm{~km} / \mathrm{s})$ were found beneath the southern Caspian and Black Sea basins (Al-Lazki et al., 2004; Ritzwoller et al., 2002). Regional scale surface wave and gravity studies suggest a thickened crust beneath the Caucasus mountains, with maximum Moho depths of $\sim 60 \mathrm{~km}$ (Ruppel and McNutt, 1990).

A good resolution 3-D velocity model of Caucasus remains to be done to provide accurate travel-times for reliable determination of earthquake locations. Largescale models obtained by the teleseismic tomography technique generally cannot resolve vertical variations in the shallow structure. Regional models can be combined in order to cover a large area, but such models cannot guarantee smooth and consistent transitions between different regions. The large database of highquality recorded arrival-times in the study area provides an unprecedented opportunity to determine a detailed 3 -D crustal structure under the region. Therefore, we introduce a method that constructs a 3-D P-velocity model for the whole Caucasus area based on observed travel-time data.

We first construct a Pn model following Hearn's (1996) method and obtain a $1^{\circ} \times 1^{\circ}$ layered 3 -D model using the adaptive moving window (AMW) method (Sun et al., 2004). We use an extensive catalog of forty years of earthquake arrival-time data between 1964 and 2010. These models are used as starting models of the 3-D tomography.

\section{Pn tomography}

Following Hearn's (1996) approach and computation method, Pn travel-time residuals are inverted for the lateral velocity variation and anisotropy within the mantle lid. Within the epicentral distances considered in this study, the Pn ray paths can be modeled as refracted rays traveling along the Moho discontinuity. The variation of seismic velocity within the uppermost mantle is parameterized by subdividing the surface of the uppermost mantle in a 2-D grid of square cells with dimensions of $30 \mathrm{~km}$ by $30 \mathrm{~km}$. The Pn travel-time residuals 
are described as the sum of three time terms:

$$
t_{i j}=a_{i}+b_{j}+\sum d_{i j k}\left(s_{k}+A_{k} \cos 2 \varphi+B_{k} \sin 2 \varphi\right)
$$

where $t_{i j}$ is the travel time residual for the ray from event $j$ to station $i ; a_{i}$ is the static delay for station $i$, depending on the crust thickness and velocity beneath the station; $b_{j}$ is the static delay for event $j$, not only depending on the crust thickness and velocity beneath the event, but also on the event focal depth; $d_{i j k}$ is the distance traveled by ray $i j$ in mantle cell $k ; s_{k}$ is the slowness perturbation for cell $k ; A_{k}$ and $B_{k}$ are the anisotropic coefficients for cell $k$; and $\varphi$ is the back azimuth angle. The unknown quantities in the equation are $a_{i}, b_{j}, s_{k}, A_{k}$ and $B_{k}$. As a first approximation, seismic anisotropy in the mantle is assumed to be described by a $2 \varphi$ azimuthal variation. The magnitude of anisotropy for cell $k$ is given by $\sqrt{A_{k}^{2}+B_{k}^{2}}$ and the azimuthal angle $\Theta$ of the fast direction of Pn propagation is given by $90^{\circ}+\left[\arctan \left(B_{k} / A_{k}\right)\right] / 2$. The sum is calculated over all cells through which the ray travels in the uppermost mantle. Further details of the tomography technique used here can be found in Hearn (1996). A set of Laplacian damping equations regularizes the solution, and two damping constants are separately applied to the unknown slowness and anisotropic coefficients. A proper pair of damping constants is chosen to balance the error size and the resolution width. In this approach the trade-off between velocity and anisotropy is a crucial issue, which has been examined by using different combinations of damping parameters for both velocity and anisotropy. In this study the main features of the velocity and anisotropy fields are observed to be significantly stable, even though the extent of the velocity anomalies and the amount of anisotropy vary slightly for different combinations of the damping constants.

Figures 1 through 5 show preliminary results of applying this tomography method to the CauSIN time picks database, which has been recently extended to include data from local Turkish networks. Figure 1 shows the ray paths used in the tomography; there are 41682 Pn rays from 5465 events to 245 stations. Figure 2 shows preliminary results of 3-D tomography for lateral variations in $\mathrm{Pn}$ velocity. Areas of thicker continental crust throughout the central Caucasus show lower velocities, while the oceanic crust under the Black and Caspian seas show higher velocities. In general, our Pn results in the South Caspian basin are consistent with those obtained by Knapp et al. (2004) using deep seismic reflection profiling. The region of higher velocity under the eastern portion of Azerbaijan is most likely due to high velocities in the oceanic crust under the South Caspian sea. Poor coverage of ray paths in this part of the study area has resulted in smearing the feature toward the west. Similarly, the high velocity in the northern part of the image is most likely from a basin structure north of the Greater Caucasus. Figure 3 shows station delays for Pn travel-times, while Figure 4 shows event delays for Pn travel-times. Finally, Figure 5 shows travel-time residuals before and after inversion. The standard deviation of travel-time residuals is reduced from $1.28 \mathrm{~s}$ to $0.92 \mathrm{~s}$.

This tomography result will improve the coverage once data is received from our colleagues in Azerbaijan. We will also extend the study region past the Caspian Sea into central Asia when this dataset is joined with data being collected for the CASRI project in Central Asia.

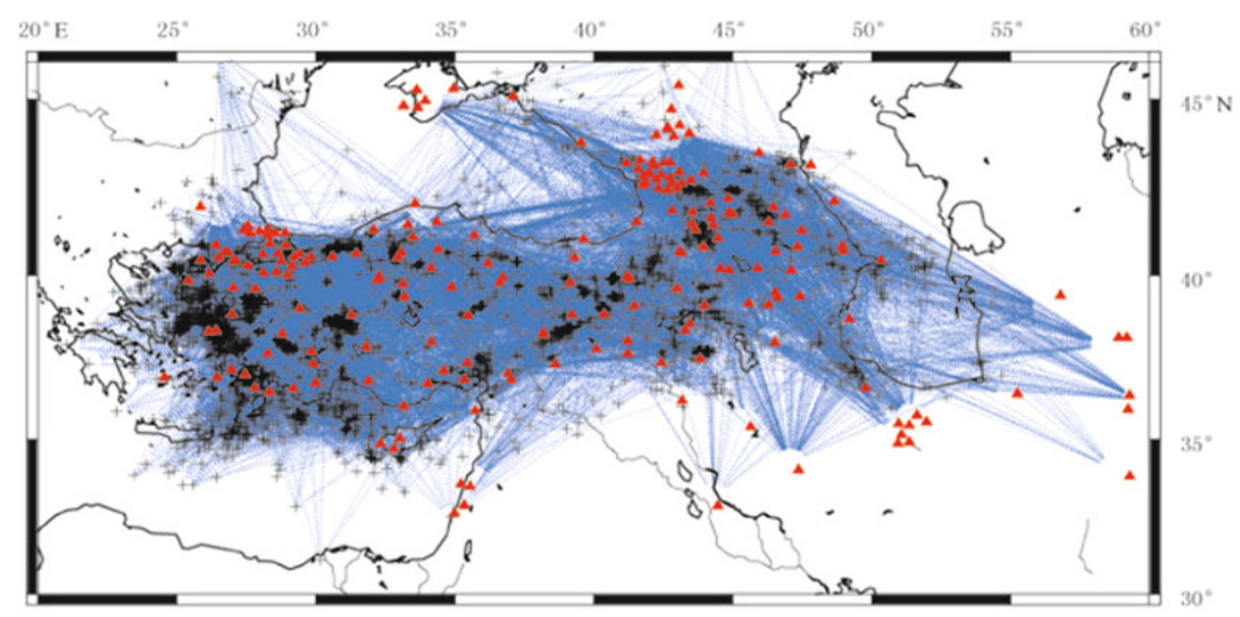

Figure 1 Ray paths for Pn travel-times. 41682 Pn rays were obtained from 5465 events (black cross) recorded by 245 stations (red triangle). 


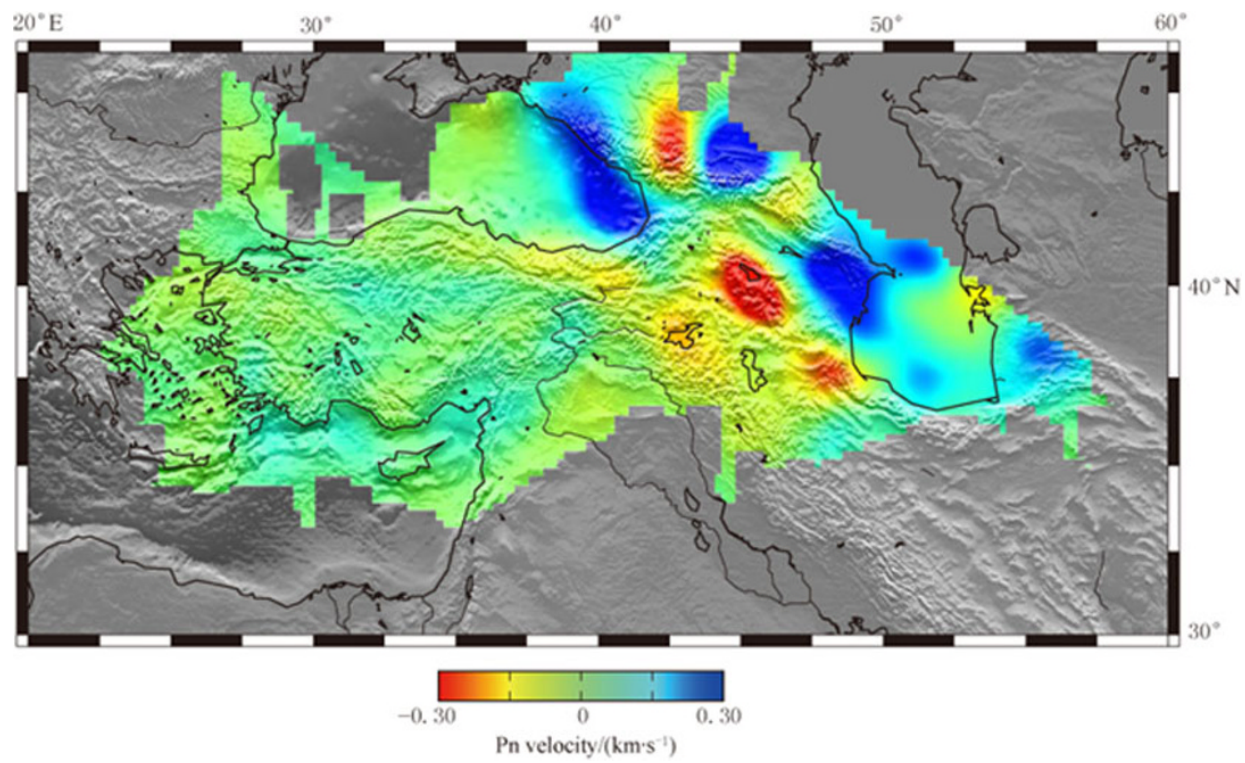

Figure 2 Imaged $P n$ velocity lateral variations. Average $P n$ velocity is $7.9 \mathrm{~km} / \mathrm{s}$ and variation corresponds with color, red represents lower velocity than the average and blue denotes higher velocity.

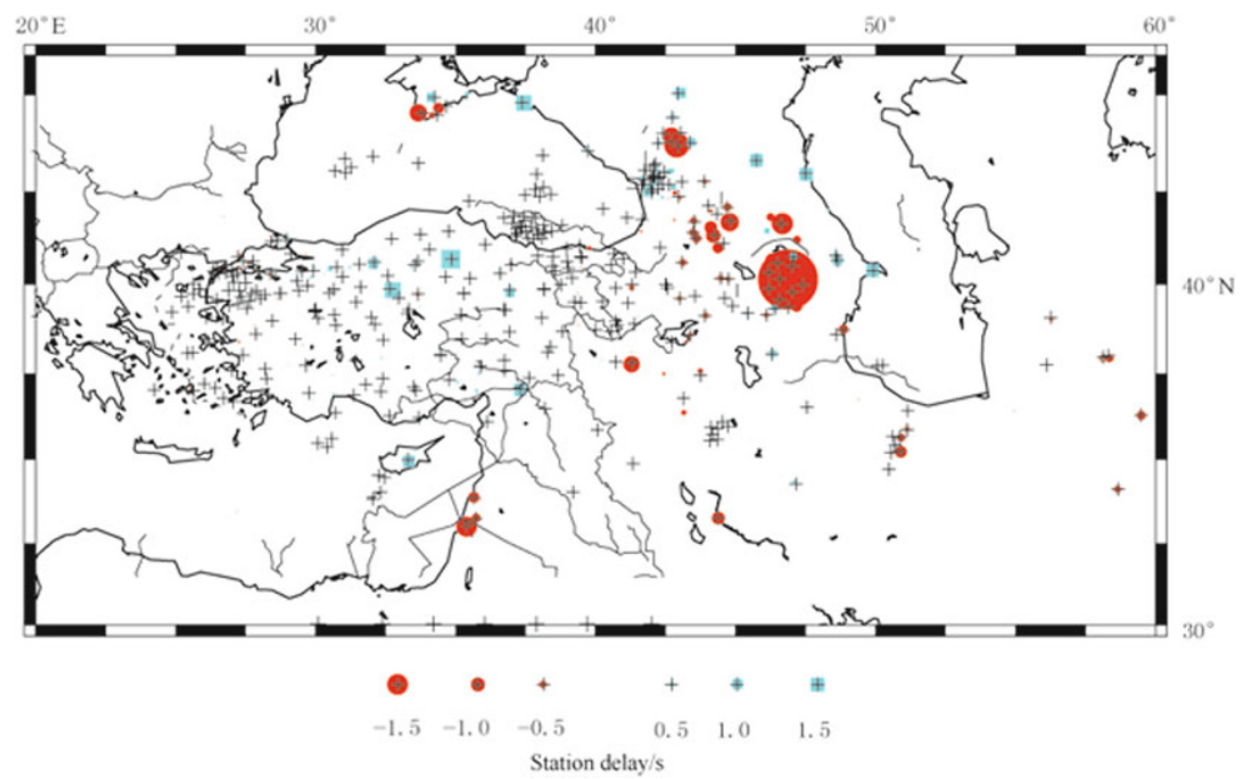

Figure 3 Station delays for Pn travel-times. Crosses represent stations, circles indicate early arrival times and squares indicate late arrival times, with their size proportional to delay amount.

\section{3-D tomography}

For this 3-D tomographic study, we use the earthquake phase data (first P-wave arrivals) from January 1964 to December 2010 in the study area. There are 43000 earthquakes, 350 stations, and 300000 ray paths in the Caucasus and the surrounding area in this database. Figures 6 and 7 show earthquake epicenters, the stations, and the ray paths.

Given that the ray coverage is denser in some areas and redundant calculation is involved, we adopted the method described below to assemble the best set of the earthquake data. The study area is divided into parallel pipedic blocks with a spatial size of $10 \mathrm{~km}$ (northing) $\times 10 \mathrm{~km}$ (easting) $\times 2 \mathrm{~km}$ (depth). Among the earthquakes within each block, we only select the event with the greatest number of first $\mathrm{P}$-wave arrivals and the smallest hypocentral location uncertainty. As a result, our final dataset contains 24000 events with more than 200000 ray paths. The final ray coverage has a better (more uniform) distribution in the study area, and it is therefore more appropriate for tomographic study than the original dataset. Since most aftershocks occurred in similar locations with smaller magnitudes 


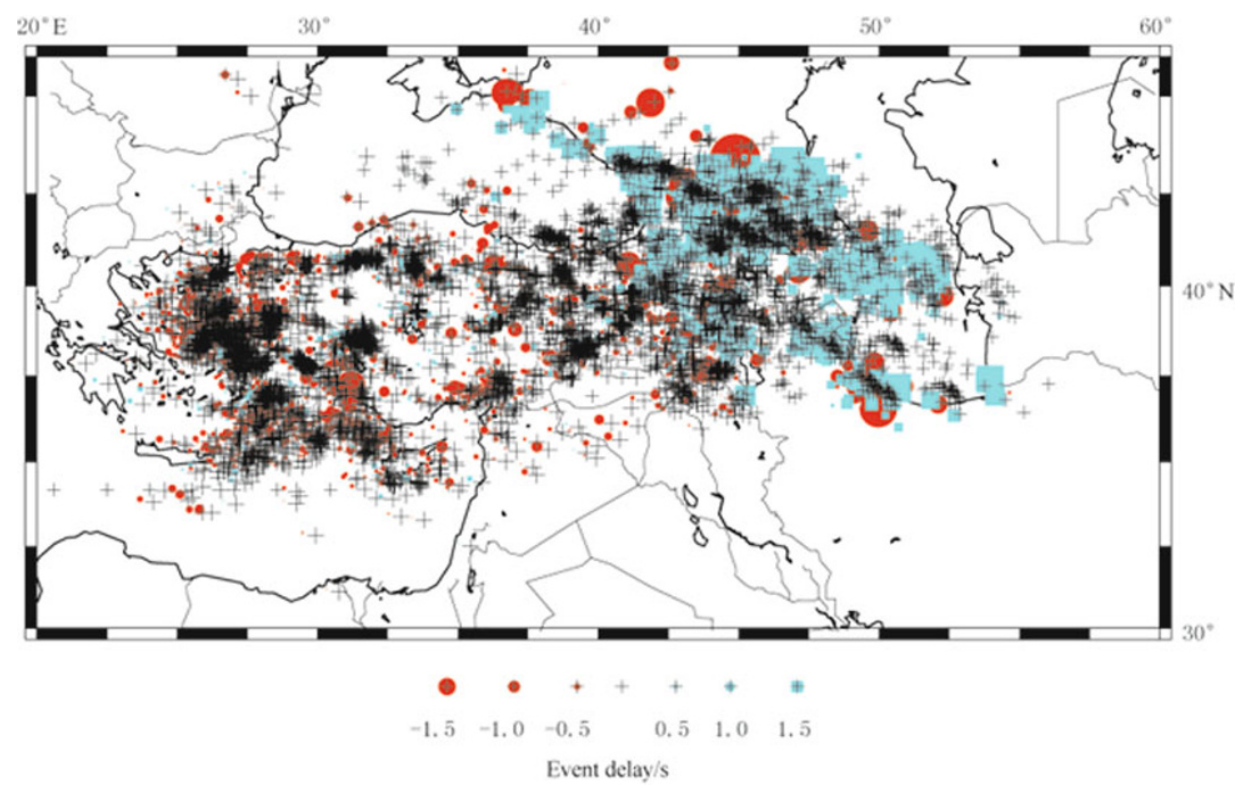

Figure 4 Event delays for Pn travel-times. Crosses represent events, circles indicate early arrival times and squares indicate late arrival times, with their size proportional to delay amount.
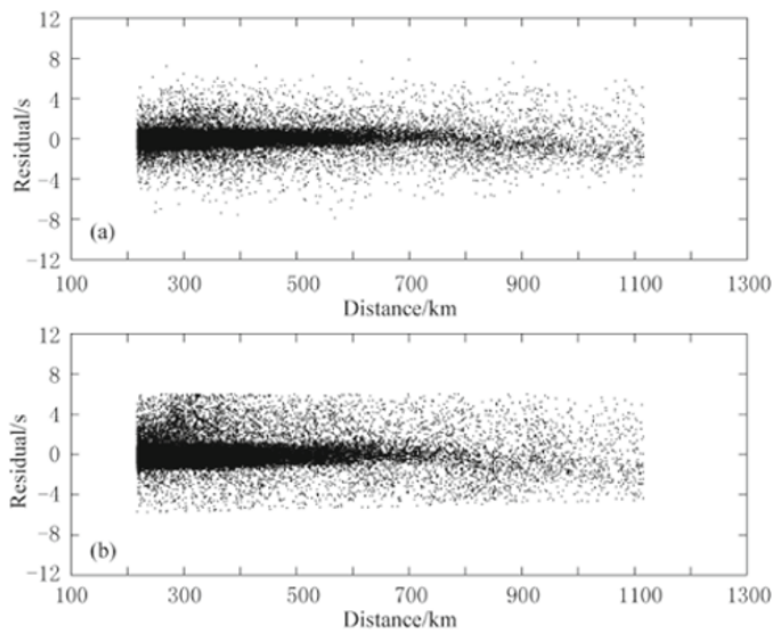

Figure 5 Travel-time residuals before inversion (a) and after inversion (b). The standard deviation of travel time residuals decreased to $0.92 \mathrm{~s}$ from $1.28 \mathrm{~s}$.

and tend to produce larger reading errors for the phase arrivals than the main shocks, the final dataset contains the least number of aftershocks.

The input and output 3-D models are represented by velocity perturbations relative to an averaged 1-D reference model in the study area. Even though the travel-times are calculated based on 3-D models, the 1-D reference model significantly influences the final result of the tomographic study because of the linearization process taken in the tomography. An inappropriate initial reference model may not only affect the quality of the three dimensional images by introducing artifacts, but it may also influence the confidence calculations by underestimating the uncertainties of the results ( $\mathrm{Yu}$ et al., 2003; Kissling et al., 1994). We inverted the arrivaltime data in our selected dataset for a 1-D velocity model representing the whole study area by minimizing the root mean square (RMS) error of the traveltimes. Finally we obtained the 1-D model which gave the best fit to the observed data. We used this averaged 1-D model as the reference velocity model for our tomographic inversions.

The discontinuities represent known geological boundaries such as the Conrad and the Moho discontinuities. Previous studies were able to map the Moho discontinuity in the study area and revealed its significant lateral depth variations (Ritzwoller et al., 1998; Hearn and Ni, 1994; Al-Lazki et al., 2004). The Conrad discontinuity is clear only in some regions of the study area, and therefore we only incorporate the Moho discontinuity in this study. The input geometry of the Moho discontinuity was compiled following Sun et al. (2004) and Sun and Toksöz (2006). The Moho depths range from $15 \mathrm{~km}$ to $45 \mathrm{~km}$. All the depths are referenced to sea level.

We applied the tomographic method of Zhao et al. (1992) for determining the crustal and uppermost mantle velocity structures in the Caucasus and the surrounding area. Zhao's method, described in detail in several papers (Zhao et al., 1992, 1994; Zhao, 2001; Sun and Toksöz, 2006), allows 3-D velocity variations everywhere in the model and can accommodate velocity discontinuities. The velocity structure is discretized using 


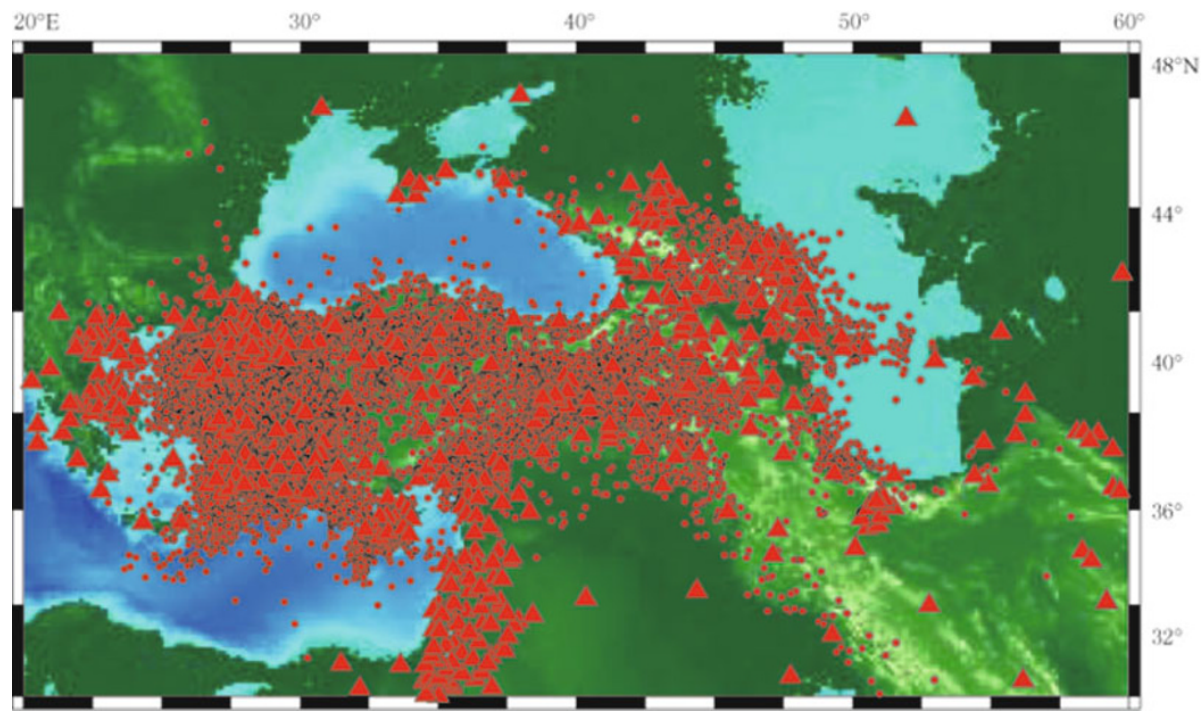

Figure 643000 earthquakes from January 1964 to December 2010 and 350 stations in Caucasus and the surrounding areas. Earthquake epicenters are shown in red dots and stations are shown in red triangles.

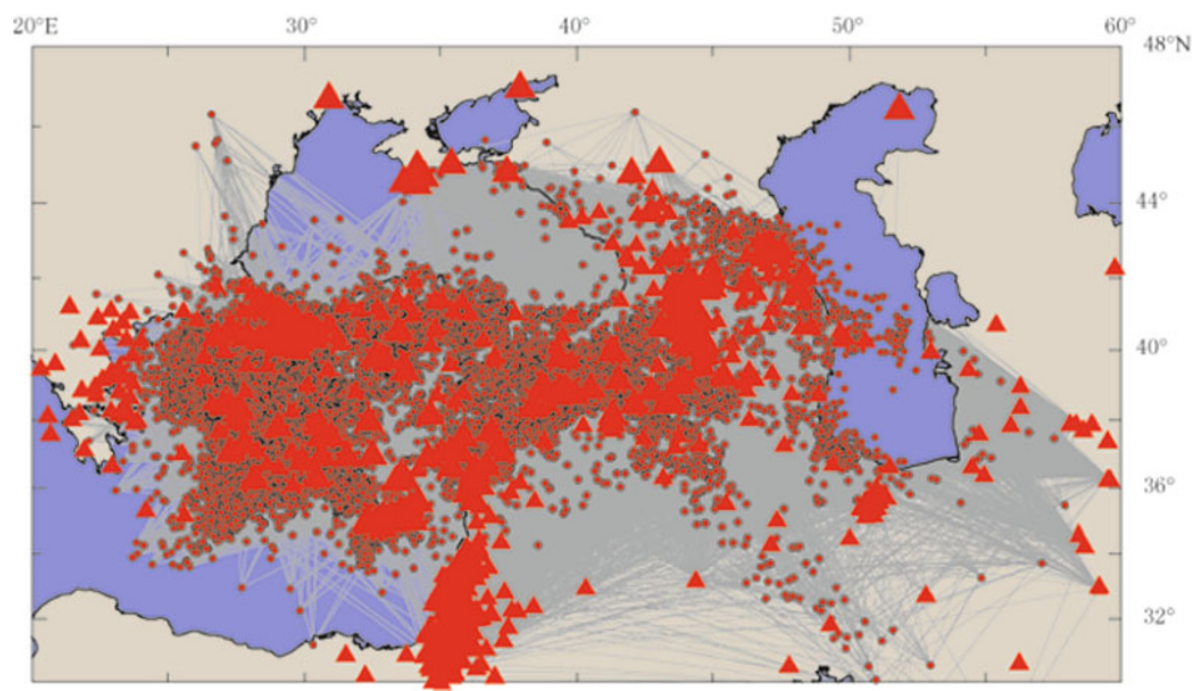

Figure 743000 earthquakes, 350 stations, and 300000 ray paths in Caucasus and the surrounding areas. Earthquake epicenters are shown in black circles and stations are shown in red triangles.

a 3 -D grid. The velocity perturbation at each point is calculated by linearly interpolating the velocity perturbations at the eight surrounding (adjacent) grid nodes. Velocity perturbations at grid nodes are the unknown parameters for the inversion procedure. To calculate travel-times and ray paths accurately and rapidly, the pseudo-bending technique (Um and Thurber, 1987) and Snell's law are used iteratively. Station elevations are taken into account as station corrections when an averaged $4 \mathrm{~km} / \mathrm{s}$ crustal velocity model was used. The LSQR algorithm (Paige and Saunders, 1982) with a damping regularization is used to solve the large and sparse system of equations. The nonlinear tomographic problem is solved by iteratively conducting linear inversions. At each iteration, perturbations to hypocentral parameters and velocity structure are determined simultaneously.

From the checkerboard resolution analyses, we adopt a grid spacing of $1^{\circ}$ in the horizontal direction, and $10 \mathrm{~km}$ in depth (Figure 8). We add grid nodes at depths of $1 \mathrm{~km}, 2 \mathrm{~km}, 5 \mathrm{~km}$, and $7 \mathrm{~km}$ to discretize the sediment layer. We chose a damping value of 25.0 from the tradeoff curve between the travel-time residuals and 
the model variance by considering the balance between the reduction of travel-time residuals and the smoothness of the 3-D velocity model obtained (EberhartPhillips, 1986). For the inversion with a damping parameter of 20.0, the RMS travel-time residual is reduced from $0.89 \mathrm{~s}$ to $0.54 \mathrm{~s}$, and the variance reduction is $60 \%$ between the initial and final 3-D models. Over $70 \%$ of the rays have residuals smaller than $0.45 \mathrm{~s}$ after the inversion. The RMS travel-time residual is about $1.1 \mathrm{~s}$ if the $1-\mathrm{D}$ reference model is used to calculate the traveltimes. The variance reduction is about $63 \%$ between the final 3-D model and the averaged 1-D model.

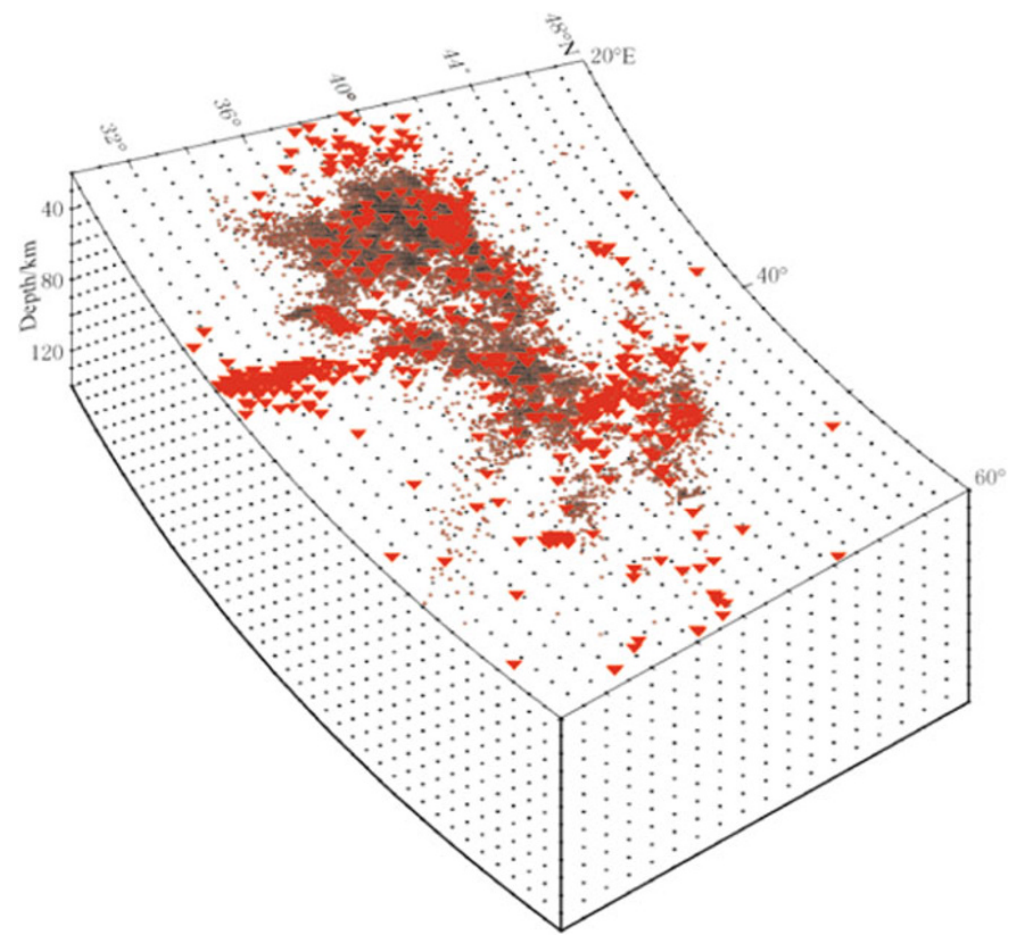

Figure 8 Three-dimensional configuration of the grid adopted in the present study. The resolution in horizontal direction is $1^{\circ}$. The resolution in vertical direction is $2 \mathrm{~km}$ (from surface to the depth of $10 \mathrm{~km}$ ) and $10 \mathrm{~km}$.

The distribution of hit counts (number of rays passing through each grid node) for each layer shows that most parts of the study area are well sampled by the rays. Intuitively, given such extensive ray coverage, we expect a model with high spatial resolution. We will examine the model resolution in a systematic manner later.

The Moho variations are shown in Figure 9. The Moho depths in the South Caspian basin are similar to those obtained by Knapp et al. (2004) using deep seismic reflection profiling. Vertical cross sections of the velocity images along the profiles denoted in Figure 10 are shown in Figures 11 and 12. The tomographic images are shown in areas with hit counts greater than 5.

Before analyzing the results of the tomographic inversion, we perform tests with synthetic data to evaluate the resolution of the tomographic image. We calculate a set of travel-time delays by tracing the corresponding rays through a synthetic structure such as checkerboard, then we invert the synthetic data for the velocity structure, and finally we compare the inversion result with the initial synthetic model. To make a checkerboard velocity model, we assign $\pm 3 \%$ velocity perturbations to the $3-\mathrm{D}$ grid nodes (Figure 13). Random errors from a normal distribution with a standard deviation of $0.1 \mathrm{~s}$ are added to the synthetic travel-times calculated from the synthetic models. Leveque et al. (1993) showed that in some cases small structures in a checkerboard test can be retrieved effectively while large structures are poorly imaged. To test for such behavior in our tomographic study, we conduct checkerboard tests with different grid spacings of $1^{\circ}, 2^{\circ}, 4^{\circ}$, and $8^{\circ}$.

Our tests show the $1^{\circ}$ velocity model is best recovered in most study areas. This correlates well with hit count distribution patterns. From these resolution tests, 
we infer that for the Caucasus and the surrounding area, the tomographic images obtained have a spatial resolu- tion of $1^{\circ}$ in the horizontal direction and $10 \mathrm{~km}$ in depth, and large-scale structures are well resolved.

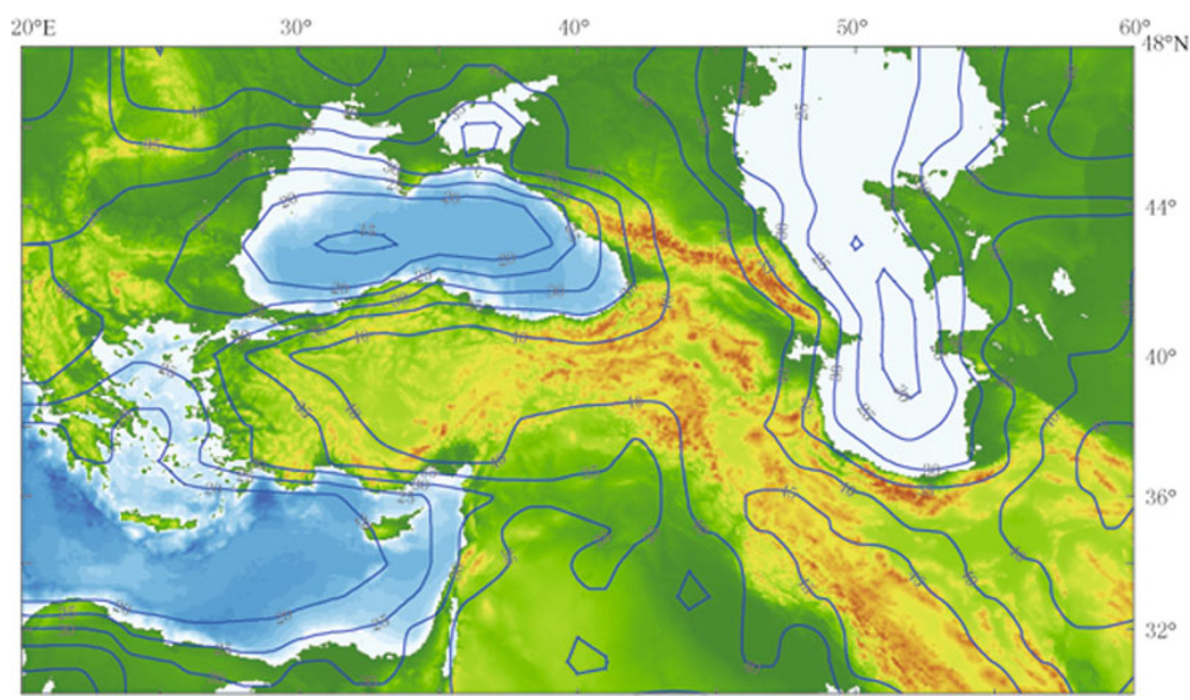

Figure 9 Depth distribution of the Moho discontinuities in the study area. The Moho depths are shown in contours. The depths of Moho are obtained by following Sun et al. (2004).

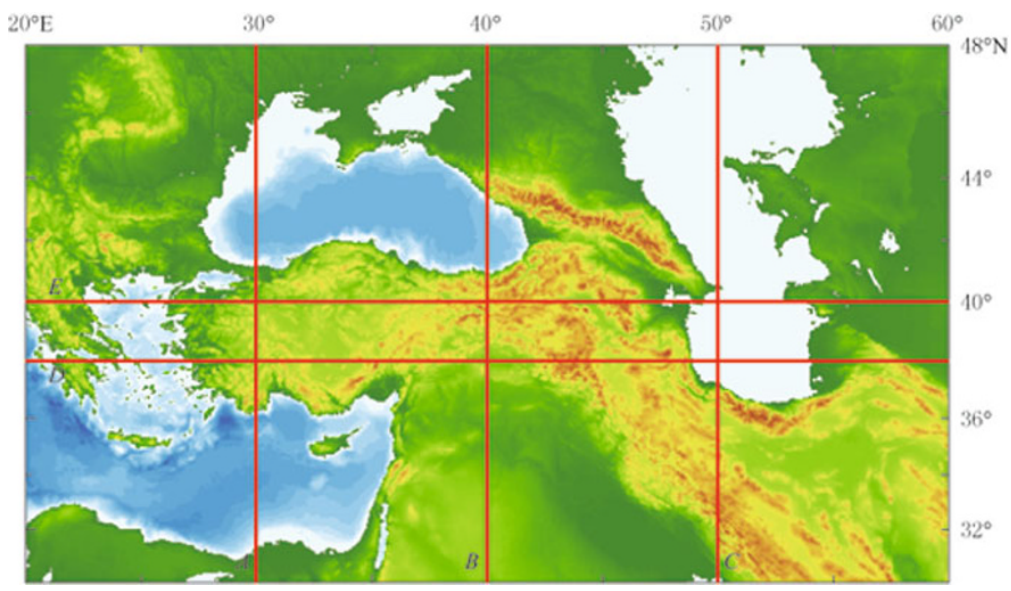

Figure 10 Locations of the vertical cross sections shown in Figures 11 and 12.
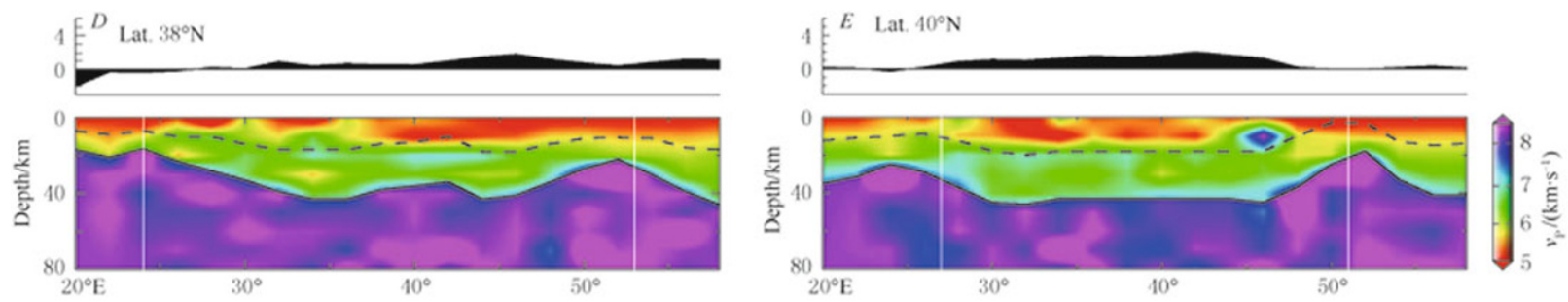

Figure 11 Vertical cross sections (shown in Figure 10) of P-wave velocity. Cross sections $D$ and $E$ at the latitudes of $38^{\circ} \mathrm{N}$ and $40^{\circ} \mathrm{N}$ are plotted. The surface topography along each profile is shown on the top of each cross section. The black curved lines show the Conrad (dashed) and Moho (solid) discontinuities. Each grid in the region between the two white lines has a raypath hit count of 300 or above. The tomographic method is given in details by Sun and Toksöz (2006). 


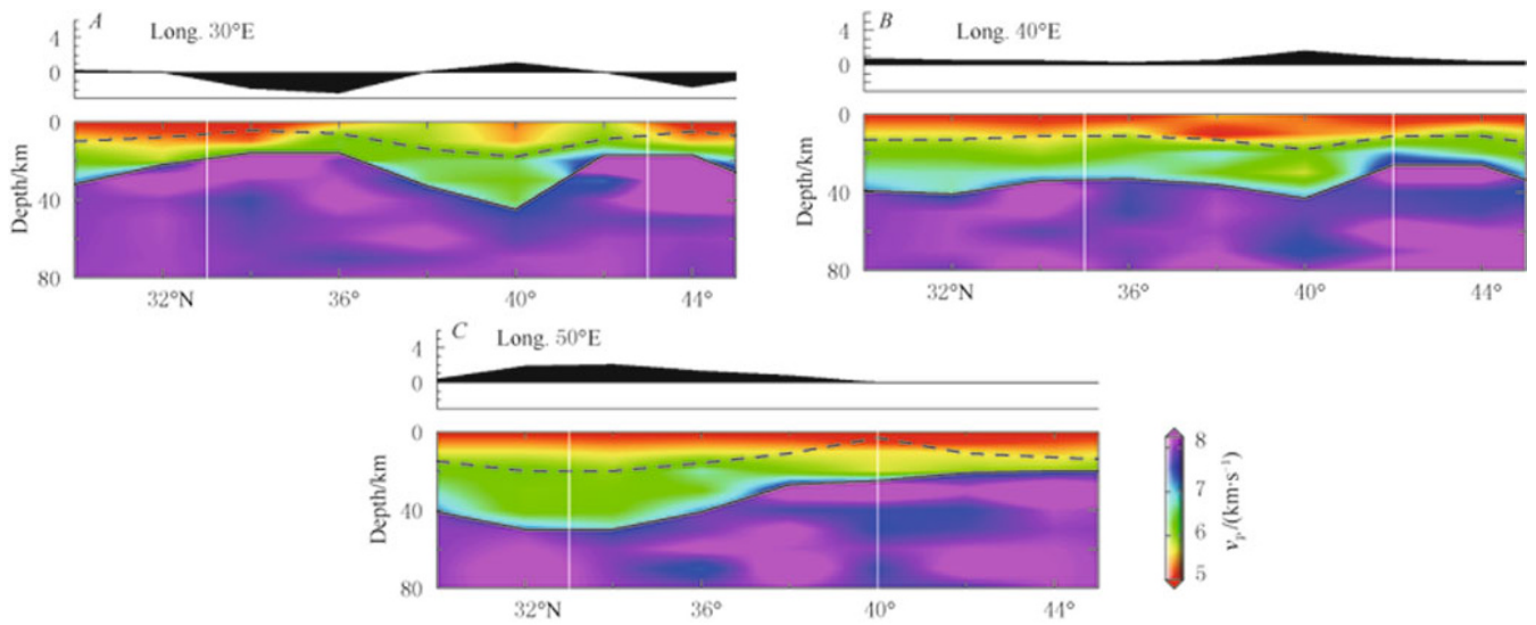

Figure 12 Vertical cross sections (shown in Figure 10) of P-wave velocity. Cross sections $A, B$, and $C$ at the longitudes of $30^{\circ} \mathrm{E}, 40^{\circ} \mathrm{E}$ and $50^{\circ} \mathrm{E}$ are plotted. The surface topography along each profile is shown on the top of each cross section. The black curved lines show the Conrad (dashed) and Moho (solid) discontinuities. Each grid in the region between the two white lines has a raypath hit count of 300 or above. The tomographic method is given in details by Sun and Toksöz (2006).

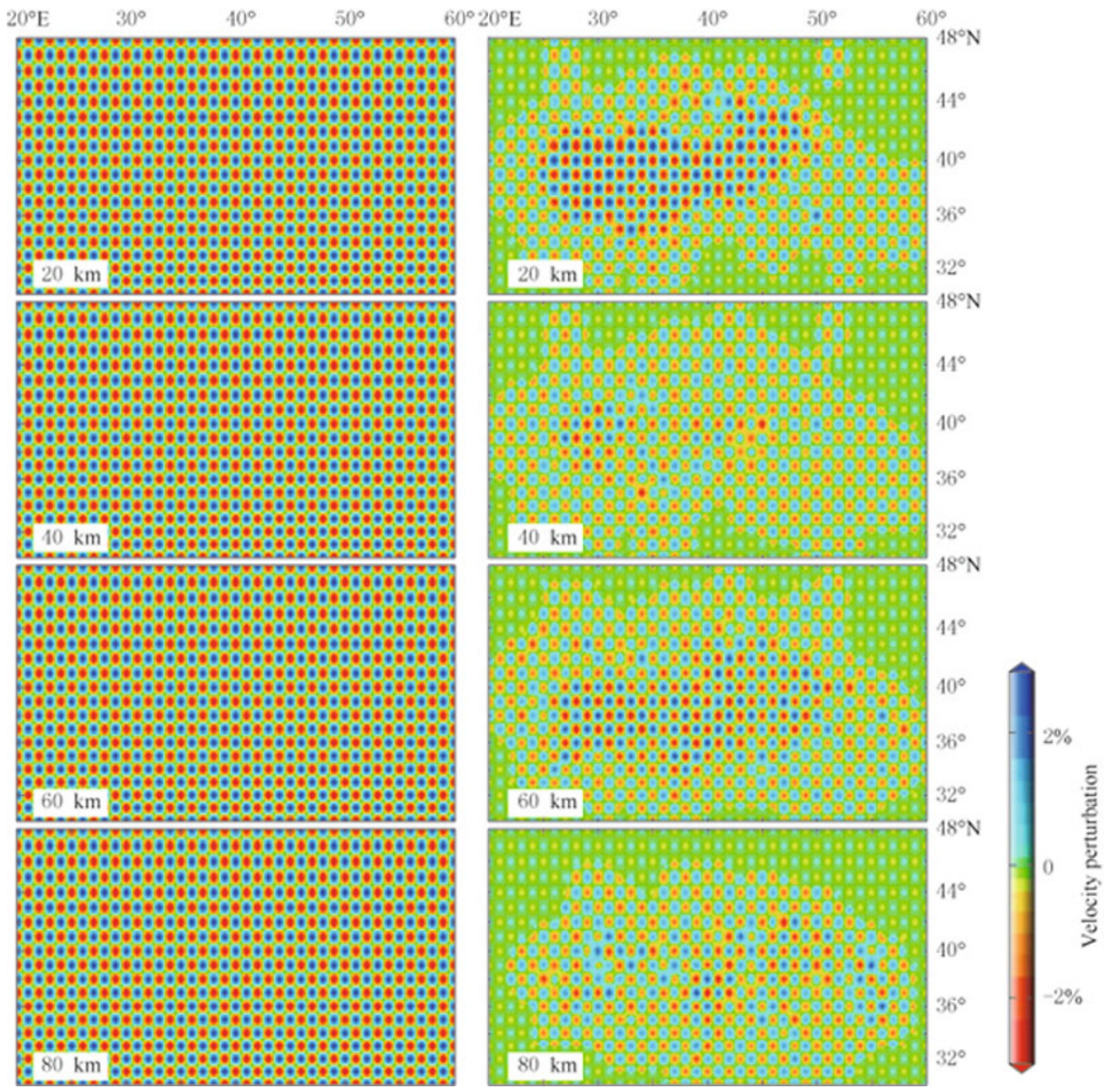

Figure 13 The input checkerboard (left) and results (right) at different depths when the grid shown in Figure 8 is adopted. The depth of the layer is shown at the lower-left corner of each map. Blue and red squares denote high and low velocities, respectively. The velocity perturbation scale is shown at the bottom. 


\section{Results and conclusions}

Strong $\mathrm{P}$-wave velocity variations of more than $6 \%$ found in the study area indicate the existence of significant structural heterogeneities in the crust and uppermost mantle in this region. The Pn velocities shown in Figure 2 have similar features to those obtained by Al-Lazki et al. (2004). High Pn velocities are dominant under eastern Azerbaijan/southern Caspian and under eastern Black Sea. The extent of the anomalies require further confirmation. Because of the distribution of earthquake epicenters and stations, rays traversing the area are mostly NW-SE. It is important to ensure that there is no "smearing" along the dominant ray direction.

We are in the process of extending our data coverage to the south and east, which should improve the image of the high velocity zone under the south Caspian Sea. It will be more difficult to improve data coverage in the north, as there is very little seismicity north of the Greater Caucasus and very few stations. We hope that combining this data with data from networks in the Central Asian countries (as part of the CASRI project) will be beneficial to the image quality in the northern and eastern region of the CauSIN study area.

The Moho discontinuity plays an important role in tomography. The importance of taking into account the Moho depth variations and other discontinuities in the tomographic inversion has also been demonstrated in the earlier studies of the Japan and Tonga subduction zones (Zhao et al., 1992, 1997), Southern Carpathians, Romania (Fan et al., 1998), and China (Sun and Toksöz, 2006). When the discontinuity topography is taken into account, ray paths and travel-times can be computed more accurately, and therefore a better tomographic result is expected. Sun and Toksöz (2006) shows that the final RMS travel-time residual is $0.58 \mathrm{~s}$ for the inversion when the Moho topography is considered, $6 \%$ lower than the $0.62 \mathrm{~s}$ RMS residual with the flat Moho $(50 \mathrm{~km})$, the average Moho depth in China.

While the Moho depths are fixed as the initial model in our inversion, we conduct an inversion by allowing the Moho depths to change between $-5 \mathrm{~km}$ and $5 \mathrm{~km}$ of the initial model, and both Moho depths and velocities are unknowns in the inversion. The Moho depth difference is within $\pm 1 \mathrm{~km}$ and the Pn velocity difference is within $\pm 0.1 \mathrm{~km} / \mathrm{s}$ compared to the reference 3 -D model. Along a vertical cross section the final velocity difference is within $\pm 0.1 \mathrm{~km} / \mathrm{s}$ in the crust and uppermost mantle. The Moho depth difference along the pro- file $E$ is within $\pm 1 \mathrm{~km}$ throughout the cross section.

In summary, our velocity model shows the following features.

1) The seismic velocity images are characterized by block structures corresponding to geological features bounded by large fault zones. The trend of velocity anomalies is consistent with the trend of regional tectonics.

2) Our tomographic imaging has revealed significant velocity heterogeneities in the middle and lower crust, some of which are consistent with those detected by deep seismic soundings and other geophysical investigations.

3) Pn velocities are high under eastern Azerbaijan/ southern Caspian and under eastern Black Sea.

4) Velocity heterogeneities below Moho at Caspian zone reflect the tectonic history and ongoing subduction.

Acknowledgements This work was financially supported by the Defense Threat Reduction Agency under Contract Nos DE-AC-52-04NA25612, NNSA-03-2S2, W-7405-ENG-483, also supported by CAS fund KJCX2-EW-121. All the figures in this work are made by using GMT (Wessel and Smith, 1995).

\section{References}

Adamia Sh A, Lordkipanidze M B and Zakariadze G S (1977). Evolution of an active continental margin as exemplified by the Alpine history of the Caucasus. Tectonophysics 40: 183-199.

Al-Lazki A I, Sandvol E, Seber D, Barazangi M, Turkelli N and Mohamad R (2004). Pn tomography imaging of mantle lid velocity and anisotrophy at the junction of the Arabian, Eurasian and African plates. Geophy J Int 158: 1 024-1 040.

Cisternas A and Philip H (1997). Seismotectonics of the Mediterranean region and the Caucasus. In: Giardini $\mathrm{D}$ and Balassanian S eds. Historical and Prehistorical Earthquakes in the Caucasus. NATO ASI Ser. Environ., Kluwer Academic Publishers, 28: 39-77.

Eberhart-Phillips D (1986). Three dimensional velocity structure in Northern California Coast Ranges from inversion of local earthquake arrival times. Bull Seismol Soc Am 76: 1 025-1 052.

Fan G, Wallace T and Zhao D (1998). Tomographic imaging of deep velocity structure beneath the eastern and southern Carpathians, Romania: Implications for continental collision. J Geophys Res 103: 2 705-2 723.

Hearn T M (1996). Anisotropic Pn tomography in the western United States. J Geophys Res 101: 8 403-8 414.

Hearn T M and Ni J (1994). Pn velocities beneath continen- 
tal collision zones: The Turkish-Iranian plateau. Geophys $J$ Int 117: 273-283.

Jackson J (1992). Partitioning of strike-slip and convergent motion between Eurasia and Arabia in eastern Turkey and the Caucasus. J Geophys Res 97: 12 471-12 479.

Jackson J and McKenzie D P (1984). Active tectonics of the Alpine-Himalayan belt between western Turkey and Pakistan. Geophys J R astr Soc 77: 185-264.

Jackson J, Priestley K, Allen M and Berberian B (2002). Active tectonics of the South Caspian Basin. Geophys $J$ Int 148: 214-245.

Khain V E (1984). The Alpine-Mediterranean fold belt of the U.S.S.R. Episodes 7: 20-29.

Kissling E, Ellsworth W L, Eberhart-Phillips D and Kradolfer U (1994). Initial reference models in local earthquake tomography. J Geophys Res 99: 19 63519646.

Knapp C, Knapp J and Connor J A (2004). Crust-scale structure of the South Caspian Basin revealed by deep seismic reflection profiling. Mar Pet Geol 21: 1 0731081.

Koçyiğit A, Yılmaz A, Adamia Sh A and Kuloshvili S (2001). Neotectonics of east Anatolian Plateau (Turkey) and Lesser Caucasus: Implications for transition from thrusting to strike-slip faulting. Geodinamica Acta 14: 177195.

Leveque J, Rivera L and Wittlinger G (1993). On the use of the checkerboard test to assess the resolution of tomographic inversions. Geophys J Int 115: 313-318.

Mangino S and Priestley K (1998). The crustal structure of the southern Caspian region. Geophys J Int 133: 630648 .

McClusky S, Balassanian S, Barka A, Demir C, Ergintav S, Georgiev I, Gurkan O, Hamburger M, Hurst K, Kahle H, Kastens K, Kekelidze G, King R, Kotzev V, Lenk O, Mahmoud S, Mishin A, Nadariya M, Ouzounis A, Paradissis D, Peter Y, Prilepin M, Reilinger R, Sanli I, Seeger H, Tealeb A, Toksöz M N and Veis G (2000). Global positioning system constraints on plate kinematics and dynamics in the eastern Mediterranean and Caucasus. J Geophys Res 105: 5 695-5 719.

McKenzie D (1972). Active tectonics of the Mediterranean region. Geophys J R astr Soc 30: 109-185.

Paige C and Saunders M (1982). LSQR: An algorithm for sparse linear equations and sparse least squares. $A C M$ Trans Math Software 8: 471.

Reilinger R, McClusky S, Vernant P, Lawrence S, Ergintav S, Cakmak R, Ozener H, Kadirov F, Guliev I, Stepanyan R, Nadariya M, Hahubia G, Mahmoud S, Sakr K, ArRajehi A, Paradissis D, Al-Aydrus A, Prilepin M, Guseva T, Evren E, Dmitrotsa A, Filikov S V, Gomez F, AlGhazzi R and Karam G (2006). GPS constraints on continental deformation in the Africa-Arabia-Eurasia con- tinental collision zone and implications for the dynamics of plate interactions. J Geophys Res 111: B05411, doi:10.1029/2005JB004051.

Reilinger R E, McClusky S C, Souter B J, Hamburger M W, Prilepin M T, Mishin A and Guseva T (1997). Preliminary estimates of plate convergence in the Caucasus collision zone from Global Positioning System measurements. Geophys Res Lett 24: 1 815-1 818.

Ritzwoller M, Levshin A, Ratnikova L and Egorkin A (1998). Intermediate-period groupvelocity maps across Central Asia, western China, and parts of the Middle East. Geophys J Int 134: 315-328.

Ritzwoller M H, Barmin M P, Villasenor A, Levshin A L and Engdahl E R (2002). Pn and Sn tomography across Eurasia to improve regional seismic event locations. Tectonophysics 358(1-4): 39-55.

Ruppel C and McNutt M (1990). Regional compensation of the Greater Caucasus mountains based on an analysis of Bouger gravity data. Earth Planet Sci Lett 98: 360-379.

Sun Y, Li X, Kuleli S, Morgan F D and Toksöz M N (2004). Adaptive moving window method for 3-D P-velocity tomography and its application in China. Bull Seismol Soc Am 94: 740-746.

Sun Y and Toksöz M N (2006). Crustal structure of China and surrounding regions from $\mathrm{P}$ wave traveltime tomography. J Geophys Res 111: B03310, doi:10.1029/2005JB003962.

Triep E G, Abers G A, Lerner-Lam A L, Mishatkin V, Zakharchenko N and Starovolt O (1995). Active thrust front of the Greater Caucasus: The April 29, 1991, Racha earthquake sequence and its tectonic implications. $J$ Geophys Res 100: 4 011-4 033.

Um J and Thurber C (1987). A fast algorithm for two-point seismic ray tracing. Bull Seismol Soc Am 77: 972-986.

Wessel P and Smith W (1995). New version of the generic mapping tools released. EOS Trans AGU 76: 329.

$\mathrm{Yu}$ X, Chen Y and Wang P (2003). Three-dimensional $\mathrm{P}$ wave velocity structure in Beijing-Tianjin-Tangshan area. Acta Seismologica Sinica 16: 1-15.

Zhao D (2001). New advances of seismic tomography and its applications to subduction zones and earthquake fault zones: A review. The Island Arc 10: 68-84.

Zhao D, Hasegawa A and Horiuchi S (1992). Tomographic imaging of $\mathrm{P}$ and $\mathrm{S}$ wave velocity structure beneath northeastern Japan. J Geophys Res 97: 19 909-19 928.

Zhao D, Hasegawa A and Kanamori H (1994). Deep structure of Japan subduction zone as derived from local, regional and teleseismic events. J Geophys Res 99: 22 23122329.

Zhao D, Xu Y, Wiens D, Dorman L, Hilderbrand J and Webb S (1997). Depth extent of the Lau back-arc spreading center and its relation to subduction processes. Science 278: 254-257. 